\title{
Perceptions of dentists about care of HIV infected patients
}

\author{
Percepção dos cirurgiões-dentistas sobre atendimento a pacientes infectados pelo HIV \\ Percepción de los cirugía-dentistas sobre atención a pacientes infectados por el VIH
}

Received: 06/17/2021 | Reviewed: 06/22/2021 | Accept: 06/28/2021 | Published: 13/07/2021

\author{
Aila Maria Cipriano Leal \\ ORCID: https://orcid.org/0000-0001-7266-7013 \\ University of Campinas, Brazil \\ E-mail: ailamc1@hotmail.com \\ Lúcia de Fátima Almeida de Deus Moura \\ ORCID: https://orcid.org/0000-0002-4112-1533 \\ Federal University of Piaui, Brazil \\ E-mail: mouraiso@yahoo.com.br \\ Marcoeli Silva de Moura \\ ORCID: https://orcid.org/0000-0002-9044-9025 \\ Federal University of Piaui, Brazil \\ E-mail: marcoeli-moura@hotmail.com \\ Cacilda Castelo Branco Lima \\ ORCID: https://orcid.org/0000-0002-2977-6035 \\ Federal University of Piaui, Brazil \\ E-mail: cacildacb@hotmail.com \\ Marina de Deus Moura de Lima \\ ORCID: https://orcid.org/0000-0002-7641-6331 \\ Federal University of Piaui, Brazil \\ E-mail: mdmlima@gmail.com
}

\begin{abstract}
Introduction: A cross-sectional observational study was performed involving 314 dentists in the city of Teresina, Piaui. Aims: The main objective of the present study was to evaluate the perception of dentists of Teresina, Piaui, in relation to the attitudes of HIV-infected patients. Material and methods: A cross-sectional survey was conducted among dentists of Teresina, Piaui. Positive perception was considered when the answer was "being able" and "not being afraid" to treat HIV-infected patients. Data were collected through a self-administered questionnaire that was statistically analysed using SPSS software version 20. Results: Most presented positive perception with regard to treating HIV-positive patients. Conclusion: Positive perception can be attributed to the continued education of these professionals.
\end{abstract}

Keywords: HIV; Dentistry; Perception.

\section{Resumo}

Introdução: Estudo observacional transversal foi realizado com 314 cirurgiões-dentistas de Teresina, Piauí. Objetivo: Avaliar a percepção de cirurgiões-dentistas no atendimento de pacientes infectados pelo HIV. Material e método: Os profissionais responderam ao questionário contendo dados referentes à formação profissional, capacidade para atendimento, medidas de prevenção, riscos ocupacionais e experiências profissionais com indivíduos infectados pelo HIV. Foi considerada percepção positiva quando a resposta era "estar apto" e "não ter receio" de atender pacientes infectado pelo HIV. Para análise dos dados, foi aplicado o teste Qui-Quadrado de Pearson, com intervalo de confiança de $95 \%$ e nível de significância $\alpha=5$. Resultados: Foi observada percepção positiva em $54,8 \%$ dos profissionais. A maioria dos dentistas $(85 \%)$ declarou-se apta ao atendimento, entretanto, $41,1 \%$ relatou ter receio de atender pacientes HIV positivos. Os profissionais que se consideraram inaptos ao atendimento atribuíram a incapacidade à falta de fundamentação teórica e prática durante a graduação e pós-graduação (82\%) ou condições de trabalho deficientes $(5,1 \%)$. Aqueles que cursaram pós-graduação demonstraram melhor percepção quanto ao atendimento de pacientes HIV positivos $(p=0,002)$. Conclusão: Percepção positiva pode ser atribuída à educação continuada dos profissionais.

Palavras-chave: HIV; Odontologia; Percepção.

\section{Resumen}

Introducción: Se realizó un estudio observacional transversal con 314 dentistas de Teresina, Piauí. Objetivo: Evaluar la percepción de los odontólogos en la atención de pacientes infectados por el VIH. Material y método: Los profesionales respondieron un cuestionario que contiene datos sobre formación profesional, capacidad de atención, medidas de prevención, riesgos laborales y experiencias profesionales con personas infectadas por el VIH. La percepción positiva se consideró cuando la respuesta era "estar en forma" y "no tener miedo" de cuidar a pacientes 
infectados por el VIH. Para el análisis de los datos se aplicó la prueba Chi-Cuadrado de Pearson, con intervalo de confianza del $95 \%$ y nivel de significancia $\alpha=5$. Resultados: Se observó percepción positiva en el 54,8\% de los profesionales. La mayoría de los dentistas (85\%) se declararon capaces de brindar atención, sin embargo, el 41,1\% informó tener miedo de atender a pacientes VIH positivos. Los profesionales que se consideraban no aptos para la atención atribuían su incapacidad a una falta de fundamento teórico y práctico durante los estudios de grado y posgrado $(82 \%)$ o deficientes condiciones laborales $(5,1 \%)$. Los que cursaron estudios de posgrado mostraron una mejor percepción sobre la atención a los pacientes VIH positivos $(p=0,002)$. Conclusión: La percepción positiva se puede atribuir a la formación continua de los profesionales.

Palabras clave: VIH; Odontología; Percepción.

\section{Introduction}

In the early $80 \mathrm{~s}$, the first cases of acquired immunodeficiency syndrome (AIDS) were described and characterized as a severe and advanced manifestation of the HIV virus infection (Barré-Sinoussi, 2010). AIDS patients are more vulnerable to opportunistic infections and neoplasias due to immunosuppression caused by a decrease in CD4+ lymphocytes and an increase in CD8+ cells (Simon, et al., 2006; Maartens, et al., 2014).

Antiretroviral therapy (ART) has provided increased life expectancy and has improved the quality of life of HIVinfected individuals (Barré-Sinoussi, 2010; Pollack, et al., 2014). However, access to dental services is still one of the limitations to the healthcare of these patients (Fox, et al., 2012; Saki, et al., 2015; Agarwal, et al., 2015).

Dental surgeons' indisposition and fears in caring for HIV-infected patients are related to prejudice, ignorance about the infection and fears of contamination by the misperception of occupational hazards (Shaghaghian, et al., 2014; Park, et al., 2011; Prabhu, et al., 2014; Skitarelic, 2006). Changes in the means of infection prevention and control have been adopted worldwide, aiming to reduce contamination risks for both professionals and patients (Cilovic-Lagarija, et al., 2014; Gledović, et al., 2015).

Access to ART has changed the epidemiological profile of HIV-infected patients and as a result, there has been a decrease in the incidence of mouth disease outbreaks. However, the demand for dental interventions for treating non-HIVrelated conditions has also increased (Pollack, et al., 2014). The aim of this study was to evaluate the dentists' perceptions of care for HIV- infected patients.

\section{Methodology}

This cross-sectional observational study was carried out after approval by the Ethics Research Committee of the Federal University of Piaui - UFPI, Teresina, Piauí, Brazil (Protocol No. 886.181) and conducted in accordance with the Declaration of Helsinki.

The sample consisted of dental surgeons (DS) enrolled in the Regional Board of Dentistry (CRO-PI), working in the city of Teresina-PI. In the period from September 2014 to April 2015, there were 1.687 professionals with active registration in the city of Teresina. For sample calculation, the Epi-Info 7.0. software was used in module STATCALC and some parameters were considered: prevalence of dentists' perception of 50\% HIV-infected patients, 5\% sample error and $95 \%$ confidence level. A correction factor of 1.0 was applied to increase accuracy and compensate for the design effect. The ideal sample for the development of this study was $313 \mathrm{CD}$. The sample size was increased by $10 \%$ to compensate for possible losses during the study, totalling a sample of 344 CD. Dentists were randomly selected by a draw, and the approach was performed in workplaces.

For methodological evaluation, a pilot study was conducted with twenty DS who did not participate in the research. No change in the initial methodology was necessary. 
Data were collected using a self-administered questionnaire that addressed socioeconomic characteristics, professional qualifications, perceptions of treating HIV-infected patients, prevention methods, professional experiences with HIV-infected patients and occupational hazards. Perception was considered positive when the answer was "being able" and "not being afraid" to treat HIV-infected patients.

Data were analysed with the Statistical Package for the Social Sciences (SPSS $®$ for Windows software, version 20.0, SPSS Inc., Chicago, IL, USA). Descriptive analysis and Pearson's chi-square test $\left(\chi^{2}\right)$ were performed to determine the association between dependent (perception of CD) and independent variables. In all analyses, significance level $\alpha=5 \%$ was considered.

\section{Results}

The sample consisted of 314 DS. There was a loss of (8.7\%) of participants, regarding professionals that improperly filled out or did not return the questionnaire.

Table 1 describes the socioeconomic and demographic aspects of the sample. Most DS had worked in public service and private offices $(51 \%)$ and had graduated from public universities $(79.6 \%)$. 
Table 1. Aspects socioeconomic and demographic of the sample.

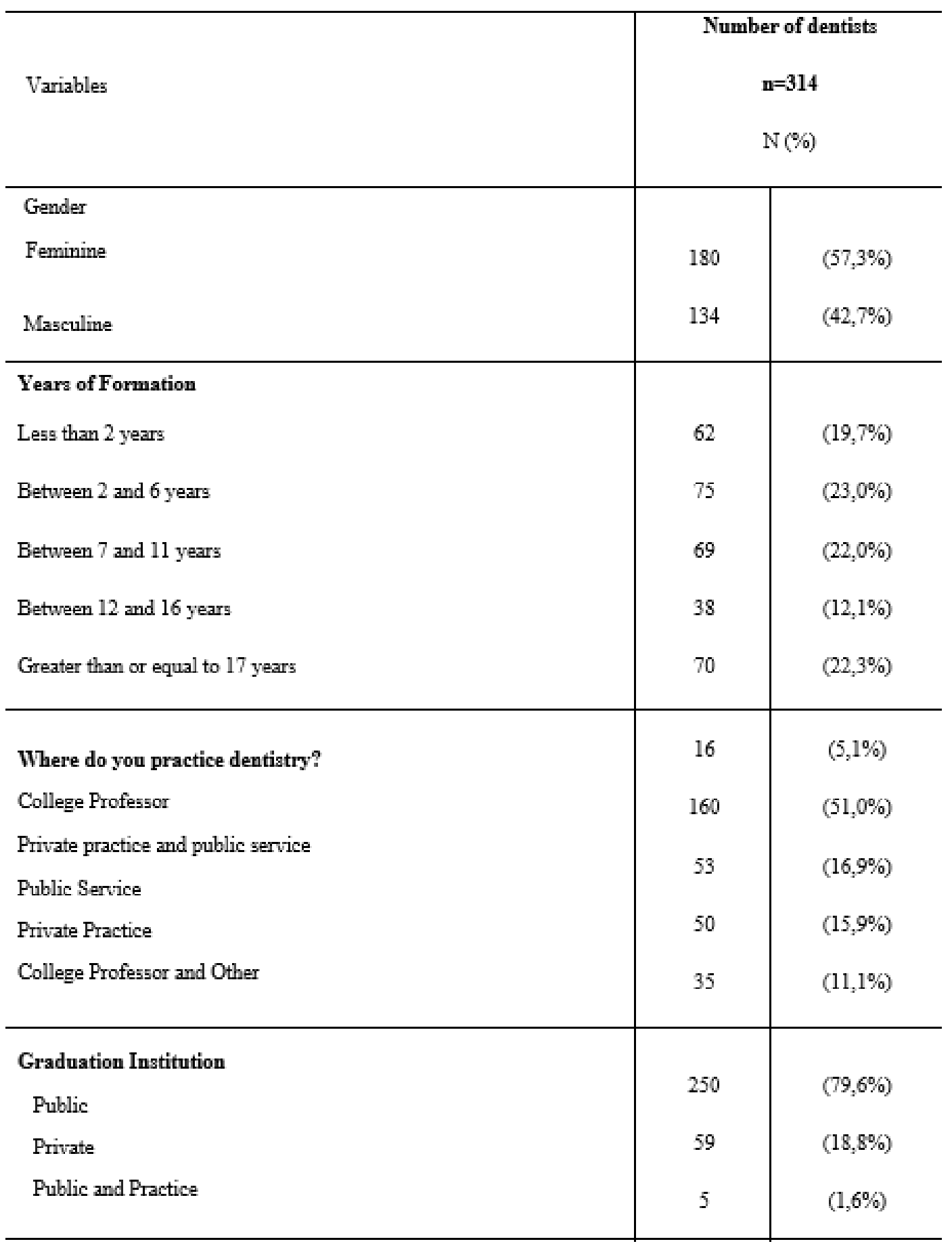

Source: Own authorship.

Most DS (85\%) reported to able to care for these patients; however, $41.1 \%$ reported fear of caring for HIV-infected patients (Table 2). Professionals who considered themselves unable for caring attributed the failure to lack of theoretical and practical knowledge $(82 \%)$ or to the poor working conditions $(5.1 \%)$ 
Table 2. Dentists'answers to questions about the care of patients infected with HIV.

\begin{tabular}{l|c|c|c}
\cline { 2 - 4 } & Yes & No & $\begin{array}{c}\text { Don't } \\
\text { know/Don't } \\
\text { remember }\end{array}$ \\
\hline Do you consider yourself qualified to attend to HIV/AIDS & 267 & 35 & 12 \\
patients? & $(85,0)$ & $(11,2)$ & $(3,8)$ \\
\hline Are you afraid to care for HIV/AIDS patients? & 129 & 185 & - \\
\hline Has there been a sharp accident during clinical care? & $(41,1)$ & $(58,9)$ & 11 \\
\hline Have you attend a patient who has declared HIV/ AIDS? & 155 & 148 & $(3,5)$ \\
\hline Did you complete the treatment? & $(49,4)$ & $(47,1)$ & 4 \\
\hline
\end{tabular}

Source: Own authorship.

Table 3 describes the professional's perception and the association with socioeconomic and knowledge variables. Positive perception was found in $54.8 \%$ of professionals. In the bivariate analysis, positive association between positive perception, type of graduation institution and graduate school formation was observed $(p<0.05)$. 
Table 3. The professional's perception and the association with socio economic and knowledge variables.

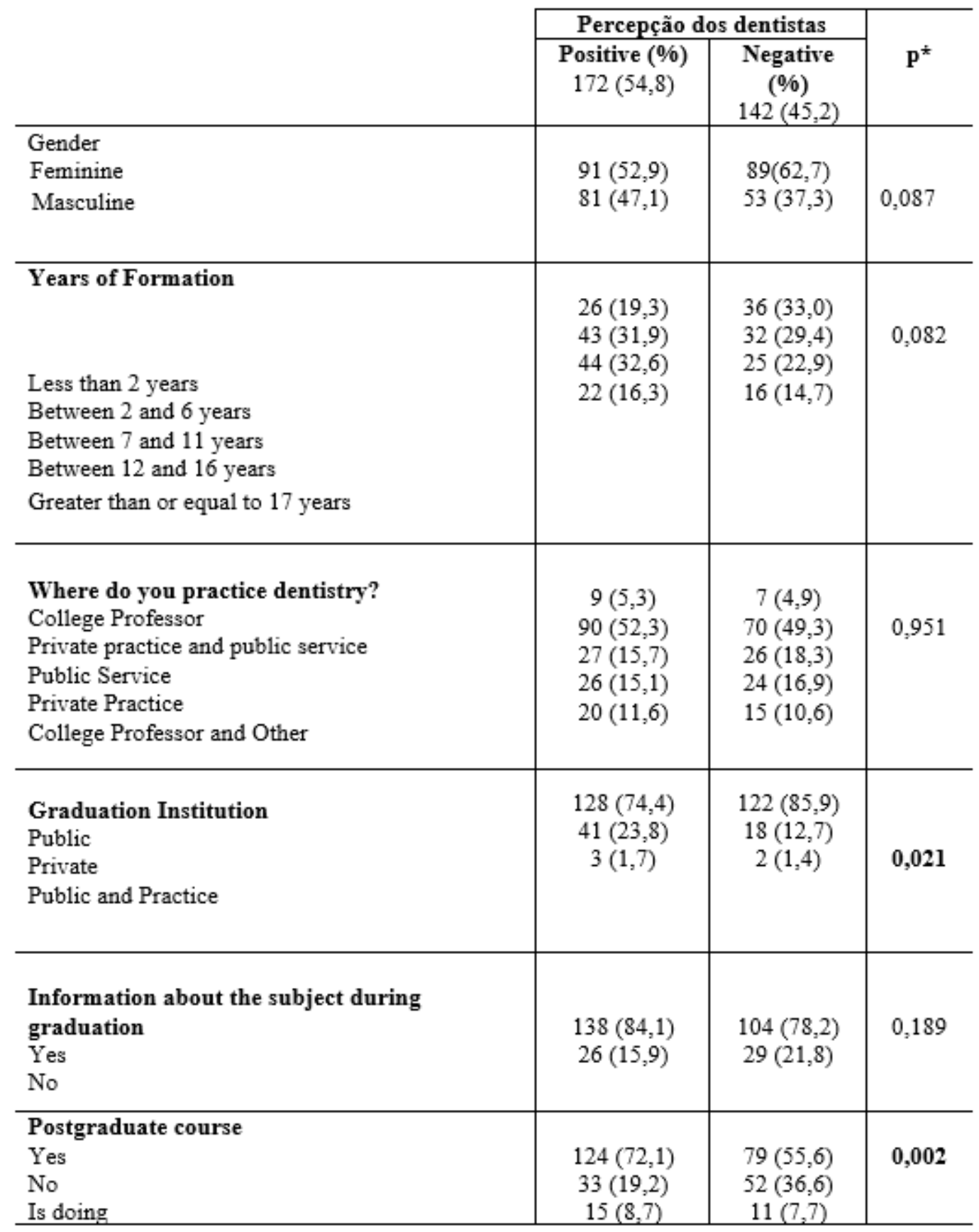

* Pearson chi-square test. Source: Own authorship.

\section{Discussion}

Due to advances in ART, increase in life expectancy and improved quality of life of HIV-infected individuals have been observed (Pollack, et al., 2014). The disease has no longer been considered a stigmatized and fatal condition and became to be treated as a chronic condition that requires continuous assistance and monitoring, which contributes to proximity between health professionals and patients (Geocze, et al., 2010; Senna, et al., 2005).

Studies have investigated professional procedures of DS in caring for HIV-infected patients, according to their knowledge of the disease (Shaghaghian, et al., 2014; Prabhu, et al., 2014; Aggarwal \& Panat, 2013; Fotedar, et al., 2012). In 
the present study, most dentists showed positive perception in caring for HIV-infected patients, a result similar to those described in other studies (Shaghaghian, et al., 2014; Park, et al., 2011).

Association between positive perception of professionals and previous professional experience was observed, highlighting the importance of interpersonal contact as a modifying factor in attitude and prejudice with regard to HIV patients. Nevertheless, many patients still do not reveal their health condition for fear of discrimination or for having their dental treatment refused (Valle, et al., 2015; Discacciati \& Vilaça, 2001; Giuliani, et al., 2005).

In recent years, there has been a change in the epidemiological scenario of HIV/AIDS (Maartens, et al., 2014) with an increase of cases among women and heterosexual adolescents, decentralizing socially marginalized groups, such as drug users, sex workers and homosexuals (Da Silva, et al., 2008). A change in the initial representation of AIDS was a positive factor in demystifying misguided fears that were widespread to the population at the beginning of the epidemic (Senna, et al., 2005).

Although the professional performance of DS has shown to be progressively more welcoming and humane in relation to the care for HIV-infected patients, discrimination, segregation and refusal to treat these patients still persists (Park, et al., 2011).

In this study, a significant number of professionals demonstrated negative perception with regard to care for HIVinfected individuals. The physical proximity of DS to the patient's fluids, such as blood and saliva, may be the main causes of fear among these professionals. The use of individual protection equipment and adherence to biosafety norms in the care of all patients must be highlighted (Shaghaghian, et al., 2014).

Among professional participants in the present study, a high number of DS reporting episodes of accidents with sharp objects was observed. The risk of HIV contamination through this type of accident is low (Cardo, et al., 1997); however, it can become a way of cross-contamination when professionals do not follow biosafety norms (Shaghaghian, et al., 2014; Uti, et al., 2009). Professionals must know the protocol to be adopted in cases of accidental exposure to biological material (Kohn, et al., 2003). After the accident, the professional must wash the affected area properly and, along with the patient, seek an infection control service (Shaghaghian, et al., 2014).

Lack of knowledge is one of the factors that lead to negative attitudes with regard to the dental care of HIV-infected patients (Park, et al., 2011). Most professionals interviewed in this study reported receiving information on HIV patient care during undergraduate studies; however, the main justification for the inability to provide care for these patients was the poor knowledge acquired. The inconsistency of information about the protocol for the care of patient with HIV or other infectious contagious diseases generates fear among professionals (Park, et al., 2011; Fotedar, et al., 2012).

In the present study, positive association between positive perception and professionals that have attended graduate school was found. A similar study has shown that professionals who are more qualified tend to show less fear in treating HIVinfected patients (Vijayalaxmi, et al., 2014).

It is important, even during undergraduate studies, that the courses' topics concentrate on care for patients with infectious-contagious diseases, and the DS that work in public health need to be educated and updated on bioethical aspects related to HIV infection (Aggarwal \& Panat, 2013).

\section{Conclusion}

Most DS presented positive perception with regard to caring for HIV-positive patients, a condition that can be attributed to the continued education of these professionals and their previous professional experiences with HIV-positive patients. 


\section{Acknowledgments}

We thank the volunteers who kindly participated in the study carried out.

\section{References}

Agarwal, J., Agarwal, R. S., Shrivastava, A., \& Shrivastava, S. (2015). Analysis of Information, Impact and Control of HIV amongst Dental Professionals of Central India. J Clin Diagn Res, 9(7):ZC80-4. 10.7860/JCDR/2015/14300.6236.

Aggarwal, A., \& Panat, S. R. (2013). Knowledge, Attitude and Behavior in Managing Patients with HIV/AIDS Among a Group of Indian dental Students. Journal of Dental Education, 77(9):1209-1213.

Barré-Sinoussi, F. (2010). HIV: a discovery opening the road to novel scientific knowledge and global health improvement. Virology, $397(2)$ : $255-259$.

Cardo, D. M., Culver, D. H., Ciesielski, C. A., Srivastava, P. U., Marcus, R., Abiteboul, D., Heptonstall, J., Ippolito, G., Lot, F., Mckibben, P. S., \& Bell, D. M., and The Centers For Disease Control And Prevention Needlestick Surveillance Group. (1997). A case-control study of seroconversion in health care workers after percutaneous exposure. N Engl J Med, 337:1485-1490.

Cilovic-Lagarija, S., Musa, S., Brankovic, S., \& Selimovic-Dragas, M. (2014). Knowledge About Spread of HIV Infection Among Dentists Employed in Private and State Practice. Mater Sociomed, 26(2): 96-99.

Da Silva, Z. J., Oliveira, I., Andersen, A., Dias, F., Rodrigues, A., Holmgren, B., Andersson, S., \& Aaby, P. (2008). Changes in prevalence and incidence of HIV-1, HIV-2 and dual infections in urban areas of Bissau, Guinea-Bissau: is HIV-2 disappearing? AIDS, 22(10):1195-1202.

Discacciati, J. A. C., \& Vilaça, E. L. (2001). Atendimento odontológico ao portador do HIV: medo, preconceito e ética profissional. Rev Panam Salud Publica, 9(4):234-239.

Fotedar, S., Sharma, K. R., Sogi, G. M., Fotedar, V., \& Chauhan, A. (2012). Knowledge and Attitudes about HIV/AIDS of students in H.P Government Dental College and Hospital, Shimla, India. Journal of Dental Education, 77(9): 1218-24.

Fox, J. E., Tobias, C. R., Bachman, S. S., Reznik, D. A., Rajabiun, S., \& Verdecias, N. (2012). increasing access to oral health care for people living with HIV/AIDS in the U.S.: baseline evaluation results of the Innovations in Oral Health Care Initiative. Public Health Rep, 127(2):5-16.

Geocze, L., Mucci, S., De Marco, M. A., Nogueira-Martins, L. A., \& Citero, V. A. (2010). Qualidade de vida e adesão ao tratamento anti-retroviral de pacientes portadores de HIV. Rev Saúde Pública, 44(4): 743-749.

Giuliani, M., Lajolo, C., \& Rezza, G. et al. (2005). Dental care and HIV-infected individuals: are they equally treated? Community Dent Oral Epidemiol, 33: $447-453$.

Gledović, Z., Rakočević, B., Mugoša, B., \& Grgurević, A. (2015). V-related knowledge, attitudes and practice among health care workers in Montenegro. Coll. Antropol, 39(1):81-85.

Kohn, W. G., Collins, A. S., Cleveland, J. L., Harte, J. A., Eklund, K. J., \& Malvitz, D. M. (2003) Guidelines for Infection Control in Dental Health-Care Settings. The Morbidity and Mortaly Weekly Report, 19(52):1-61.

Maartens, G., Celum, C., \& Lewin, S. R. (2014). HIV infection: epidemiology, pathogenesis, treatment, and prevention. The Lancet, 384(9939):258-271.

Park, J. C., Choi, S. H., Kim, Y. T., Kim, S. J., Kang, H. J., Lee, J. H., Shin, S. C., \& Cha, Y. J. (2011). Knowledge and attitudes of Korean dentists towards human immunodeficiency vírus/acquired immune deficiency syndrome. J Periodontal Implant Sci, 41:3-9.

Pereira, A. S. et al. Metodologia da pesquisa científica. (2018). UFSM. https://repositorio.ufsm.br/bitstream/handle/1/15824/Lic_Computacao_MetodologiaPesquisa-Cientifica.pdf?sequence $=1$.

Pollack, H. A., Pereyra, M., Parish, C. L., Abel, S., Messinger, S., Singer, R., Kunzel, C., Greenberg, B., Gerbert, B., Glick, M., \& Metsch, L. R. (2014). Dentists' Willingness to Provide Expanded HIV Screening in Oral Health Care Settings: Results from a Nationally Representative Survey. American Journal of Public Health, 104(5):872- 881.

Prabhu, A., Rao, A. P., Reddy, V., Krishnakumar, R., Thayumanavan, S., \& Swathi, S.S. (2014). HIV/AIDS knowledge and its implications on dentists. Journal of Natural Science, 5(2):303-307.

Saki, M., Mohammad, K. K. S., Mohammadi, E., \& Mohraz, M. (2015). Perception of Patients with HIV/AIDS From Stigma and Discrimination. Iran Red Crescent Med J, 17(6): e23638. 10.5812/ircmj.23668v2.

Senna, M. I. B., Guimarães, M. D. C., \& Pordeus, I. A. (2005). Atendimento odontológico de portadores de HIV/AIDS: fatores associados à disposição de cirurgiões-dentistas do Sistema Único de Saúde de Belo Horizonte, Minas Gerais, Brasil. Cad. Saúde Pública, 21(1):217:225.

Shaghaghian, S., Pardis, S., \& Mansoori, Z. (2014). Knowledge, attitude and practice of dentists to wards prophylaxis after exposure to blood and body fluids. Int J Occup Environ Med, 5: 146-154.

Simon, V., Ho, D. D., \& Abdool, K. Q. (2006). HIV/AIDS epidemiology, pathogenesis, prevention, and treatment. The Lancet, 368(9534): 489-504.

Skitarelic, N. (2006). Kliničke manifestacije infekcije uzrokovane virusom humane imunodeficijencije (HIV) u otorinolaringologiji. Med Jad, 36(3-4):105112. 
Research, Society and Development, v. 10, n. 8, e30910817304, 2021

(CC BY 4.0) | ISSN 2525-3409 | DOI: http://dx.doi.org/10.33448/rsd-v10i8.17304

Uti, O. G., Agbelusi, G. A., Jeboda, S. O., \& Ogunbodede, E. (2009). Infection control knowledge and practices related to HIV among Nigerian dentists. $J$ Infect Dev Ctries, 3(8):604-610.

Valle, A., Treviño, A. C., Zambrano, F. F., Urriola, K. E., Sánchez, L. A., \& Elizondo, J. E. (2015). Perceived HIV-associated stigma among HIV-seropositive men: psychometric study of HIV stigma scale. Frontiers in Public Health, 3(171): 1-8.

Vijayalaxmi, N., Reddy, L., Swapna, L. A., Reddy, S., Ramesh, T., \& Padmareddy, M. (2014). Are you willing to treat patients with HIV/AIDS? An anonymous survey among staff and students of dental institution. Oral Health Dent Manag, 13(3):745-748. 